\title{
Efektivitas Pendidikan dan Pelatihan Teknis Petugas Lapangan Keluarga Berencana Kota Jambi
}

\section{Suwardi}

Pascasarjana UIN Sulthan Thaha Saifuddin Jambi

E-mail: suwardijambi@gmail.com

\begin{abstract}
The research is based on the increasing target and level of achievement of work plans for family planning field officers, so that education and training are needed to improve their competencies. This study aims to look at the effectiveness of technical education and training in family planning field training in improving the quality of family planning services in Jambi City. The study was conducted in qualitative method and data was collected through observation, interviews and documentation. Based on the research that has been done, it is found that 1) education and training for family planning field officers is a program that aims to increase capacity and knowledge so that services to the community increase, 2) there are still many field workers who have not received education and training in program services $K K B P K, 3)$ coverage of the task area is still limited and transportation is minimal.
\end{abstract}

Keywords: Field officer, Family Planning, Education and Training

\begin{abstract}
Abstrak: Penelitian didasarkan pada semakin meningkatnya sasaran dan tingkat pencapaian program kerja petugas lapangan keluarga berencana, sehingga diperlukan ada pendidikan dan pelatihan untuk meningkatkan kompetensi mereka. Penelitian ini bertujuan untuk melihat efektivitas pendidikan dan pelatihan teknis petugs lapangan keluarga berencana dalam peningkatan kualitas layanan keluarga berencana di Kota Jambi. Penelitian dilakukan secara kualitatif, data dikumpulkan melalui observasi, wawancara dan dokumentasi. Berdasarkan penelitian yang telah dilakukan diketahui bahwa 1) pendidikan dan pelatihan bagi petugas lapangan keluarga berencana adalah program yang bertujuan untuk meningkatkan kemampuan dan pengetahuan agar pelayanan kepada masyarakat semakin meningkat, 2) masih banyak petugas lapangan keluarga berencana yang belum mendapatkan pendidikan dan pelatihan dalam layanan program KKBPK, 3) jangkauan wilayah tugas masih terbatas dan alat transportasi minim. Kata-kata kunci: Petugas Lapangan, Keluarga Berencana, Pendidikan dan Pelatihan
\end{abstract}




\section{Pendahuluan}

Keluarga sebagai unit terkecil dalam sebuah Negara seringkali diartikan sebagai tiang utama berdirinya sebuah bangsa. Keluarga menjadi tempat persemaian nilainilai keluhuran bangsa, karena itu keluarga sejatinya menjadi pusat pembangunan sebuah bangsa. Keluarga adalah center of development. BKKBN pun menggali upaya, bagaimana memberdayakan keluarga, membangun ketahanannya, membangun kesejahtraannya, membangun karakternya dan membangun daya saingnya. Semua itu diupayakan lembaga negara non kementerian ini dengan bersendikan pada pohon besar bernama program Kependudukan, Keluarga Berencana dan Pembangunan Keluarga. Bersendikan pula pada ranting bernama “ Delapan Fungsi Keluarga" dan kini bersendikan pula pada gerakan nasional revolusi mental. ${ }^{1}$ (8 fungsi keluarga: fungsi agama, pendidikan, cinta kasih, perlindungan, reproduksi, sosial budaya, ekonomi, dan lingkungan). ${ }^{2}$ Namun tidak cukup hanya sampai disitu. Agar program berjalan tepat sasaran dengan programprogram yang ada Petugas Lapangan Keluarga Berencana (PLKB) harus diberikan pendidikan dan pelatihan tehnis dalam penyuluhan kualitas layanan KB bagi masyarakat, karena merekalah ujung tombak pencapaian program KB di lini bawah.

Pendidikan dan pelatihan bertujuan agar Petugas Lapangan Keluarga Berencana dapat memberikan pelayanan secara cepat dan akurat dan lebih profesional. Kegiatan pendidikan dan pelatihan merupakan suatu proses ataupun kegiatan yang dilakukan oleh setiap organisasi yang bertujuan untuk mengembangkan dan meningkatkan kualitas serta kemampuan Petugas Lapangan Keluarga Berencana agar mampu menghasilkan dan memberikan pelayanan yang optimal. Hal ini hanya dapat dilakukan melalui transfer pengetahuan (knowlege transfer), perubahan sikap dan perilaku tertentu. Pendidikan dan pelatihan Petugas Lapangan Keluarga Berencana haruslah dirancang sedemikian rupa sehingga pendidikan dan pelatihan tersebut dapat memberikan kontribusi yang nyata bagi para Petugas Lapngan Keluarga Berencana dalam melaksanakan tugasnya sebagai pelayan masyarakat. Oleh karenanya, melalui pendidikan dan pelatihan, diharapkan dapat melahirkan para Petugas Lapangan Kelauraha Berencana yang profesional, berprestasi, dan memiliki orientasi kedepan atau Petugas Lapangan Keluarga Berencana yang visioner dalam arti petugas tersebut setelah mengikuti pendidikan dan pelatihan

Saat ini petugas lapangan yang ada sangat sedikit jika dibandingkan dengan jumlah penduduk yang harus diberikan pelayanan tentang program-program KB di Kota Jambi. Petugas yang ada tersebut masih banyak yang baru menjadi petugas lapangan KB dan kemampuan mereka tentang program-program KB masih sangat minim, mereka belum begitu banyak yang paham tentang program-program KKBPK yang ada di BKKBN serta mereka juga belum banyak yang paham tentang alat-alat dan metode kontrasepsi KB dan obat seat efek untuk peserta KB. Baik alat KB Hormonal maupun alat KB Non Hormonal yang dibutuhkan bagi masyarakat. Sehingga pencapaian program KB di Kota Jambi belum berjalan sesuai dengan yang diharapkan. Masih banyak masyarakat yang kebutuhan KB nya belum dapat

${ }^{1}$ Budi Priyatna, DKK., Kelurga Dari Masa ke Masa (Jakarta: 2015) hlm.4

2 Budi Priyatna, DKK., Keluarga. hlm.14 
terpenuhi, dan juga masyarakat Kota Jambi masih banyak yang belum paham tentang alat $\mathrm{KB}$.

Menurut Profil Dinas Kesehatan Provinsi Jambi tahun 2012, Angka Kematian Ibu Maternal di Provinsi Jambi ada 359 kematian ibu/100.000 kelahiran hidup dan di Provinsi Jambi juga pada tahun 2010 ada 29 kematian bayi/1000 kelahiran bayi hidup. Program Keluarga Berencana (KB) adalah suatu program yang dimaksudkan untuk membantu para pasangan usia subur (PUS) dalam mencapai tujuan reproduksi mereka, mencegah kehamilan yang tidak diinginkan dan mengurangi insidens kehamilan beresiko tinggi, kesakitan dan kematian membuat pelayanan yang bermutu, terjangkau, diterima dan mudah diperoleh bagi semua orang yang membutuhkan. Dan meningkatkan partisipasi dan tanggung jawab pria dalam praktek KB.

Para petugas lapangan ini teramat perlu diberikan Pendidikan dan Pelatihan (Diklat) program-program terbarukan secara detail, pendidikan adalah sebuah kebutuhan hidup dan fungsi sosial, yang bertumpu pada masing-masing individu juga golongan. Kehidupan manusia tidak akan bertahan jika tidak ada pelatihan dan pembelajaran tentang metode-metode pekerjaan. Pendidikan memfasilitasi manusia untuk belajar dan mengetahui praktik-praktik fundamental untuk memenuhi . Pendidikan memfasilitasi manusia untuk belajar dan mengetahui praktik-praktik fundamental untuk memenuhi kebutuhan kebutuhan program kerja yang akan mereka sampaikan pada masyarakat. ${ }^{3}$

Pendidikan dan Pelatihan bagi Petugas Lapangan Keluarga Berencana dari program-program yang di berikan salah satunya adalah program tentang Vasaktomi Tampa Pisau (VTP) guna menambah kemampuan dan sikap positip terhadap manfaat dari Diklat Vasektomi tampa pisau tersebut sehingga setelah kembali dari pelatihan mereka dapat menyakinkan kepada masyarakat tentang KB pria. ${ }^{4}$

Proses belajar mengajar tersebut dengan menggunakan kurikulum 7 (tujuh) hari dari pemberian materi, pemahaman alat kontrasepsi, praktek penyampaian dan membantu proses atministrasi pada saat akan dilayani sehingga nantinya seluruh peserta mampu memberikan konseling yang baik pada klien/akseptor KB dan mereka juga nantinya diharapkan mempunyai keterampilan menghadapi kesulitan (Adversity Skills) mengubah hambatan menjadi peluang dalam bekerja, merka juga akan menjadi sumber informasi tentang program KB di wilayah tugas mereka..

Pelatihan ini dirancang untuk PLKB dan PKB di Kabupaten/Kota Provinsi Jambi. Dan materi pelajaran dikelas akan ditekankan pada masalah pelayanan yaitu bagaimana memberikan Advokasi dan KIE, konseling, seleksi klien, penanganan akibat samping dan tindakan pencegaha infeksi. 5

Dengan diadakannya pelatihan di BKKBN diharapkan nantinya para petugas lapangan dapat meningkatkan pelayan yang lebih baik bagi akseptor KB. Dengan diadakannya pelatihan di BKKBN diharapkan nantinya para petugas lapangan

3 Saidah, Pengantar Pendidikan Telaah Pendidikan Secara Global dan Nasional, (Jakarta: Rajawali Pers, 2016), hlm.7

4 Joko Raharjo.dkk, Pelatihan Keterangan Klinik (VTP),(Tahun 2008)

${ }^{5}$ Kurikulum Diklat Teknis , Direktorat Bina Ketahanan Remaja (Tahun 2013), hlm.7 
dapat meningkatkan pemberian pemahaman pelayan yang lebih baik bagi akseptor KB. Pelatihan yang ada di BKKBN ini sangat diperlukan agar tingkat pemahaman dan keterampilan diaknosa akan labih baik yang nantinya bermuara akhir bisa meningkatkan kenyamanan bagi akseptor KB dalam proses pemasangan/tindakan KB. ${ }^{6}$

Metode yang digunakan dalam penelitian ini adalah penelitian kualitatif yang berlandaskan filsafat positivism dengan pendekatan naturalistik. Subjek penelitian adalah Kepala Latbang Perwakilan BKKBN Provinsi Jambi yang diambil dengan teknik purposive sampling. Informan kunci terdiri dari Kepala Latbang Perwakilan BKKBN Provinsi Jambi, widyaiswara, TU serta staf di lingkungan Latbang ditetapkan sebagai informan tambahan, serta wanita dan pria pasangan usia subur yang tinggal di Kota Jambi di Wliayah Telanaipura Jambi. Data dikumpulkan melalui observasi, wawancara dan dokumentasi. Data dianalisis menggunaakn model analisis interaksi.

\section{Hasil dan Pembahasan}

A. Perencanaan Efektivitas Pendidikan dan Pelatihan Teknis Petugas Lapangan Keluarga Berencana dan Penyuluh Keluarga Berencana dalam Peningkatan Kualitas Layanan KB di Kota Jambi

Latbang Perwakilan BKKBN Provinsi Jambi membuat perencanaan jadwal dan tentatif kegiatan pendidikan dan pelatihan sehingga akan terlihat keluaran dan hasil materi-materi program KB yang didapat oleh petugas lapangan dalam pendidikan dan pelatihan yang akan mereka aplikasikan dalam pekerjaan mereka di wilayah tugas asing-masing petugas lapangan. Kepala Bidang Latbang mengatakan bahwasannya di Latbang Perwakilan BKKBN Provinsi Jambi ini proses kolaborasi atau kerjasama antara Dinas Instansi terkait sudah berjalan dengan baik, dalam proses kolaborasi atau kerjasama dalam upaya internalisasi nilai-nilai pendidikan agama islam kedalam program KKBPK kepada peserta didik. Untuk memvalidasi pernyataan kepala Bidang Latbang tersebut, peneliti melakukan pengamatan terhadap Widyaiswara/pendidik dengan narasumber dari Dinas Instansi terkait sudah adanya kerjasama yang dilakukan antara Widyaiswara dan Narasumber tentang program-program yang dibutuhkan bagi Petugas Lapangan Keluarga Berencana (PLKB) dalam mereka bertugas di Kab/Kota wilayah kerja mereka.

Selanjutnya kepala Latbang mengatakan bahwa, antara pendidik satu dengan pendidik yang lainnya haruslah saling bersinergi atau bekerja sama, upaya kolaborasi atau kerja sama yang dilakukan oleh pendidik dengan narasumber dari Dinas Instansi terkait dapat berupa musyawarah, dan saling bertukar pikiran program KKBPK. ${ }^{7}$

Berdasarkan hasil observasi dilapangan, ditemukan pola kolaborasi yang dilakukan antara pendidik dengan Narasumber Dinas Instansi terkait dalam upaya internalisasi nilai-nilai pendidikan program KKBPK melalui pembagian tugas yaitu melakukan pembinaan. Pembinaan yang dilakukan oelh Widyaiswara

6 Wawancara dengan Ana Triyana Palyanti, S.Pi ,( Rabu,2 November 2016)

7 Wawancara, 20 September 2017 
bagi peserta pendidikan dan pelatihan teknis Petugas Lapangan Keluarga Berencana antara lain

a. Pembinaan langsung dengan cara:

1) Memberikan materi-materi program KKBPK,

2) Menegur Petugas Lapangan Keluarga Berencana jika mereka dalam bekerja kurang maksimal memberikan layanan tentang program-program KB yang dibutuhkan oleh masyarakat, dan Petugas Lapangan Keluaraga Berencana juga dalam memberikan layanan yang melanggar norma-norma ajaran agama islam dan norma-norma yang berlaku dimasyarakat,

3) Membimbing dan mengarahkan peserta latih Petugas Lapangan Keluarga Berencana agar selalu menjalankan program-program KKBPK sesuai perintah agama dan memberikan lanyanan bagi masyarakat berbuat sesuai dengan ajaran agama islam melalui metode keteladanan

4) Memberikan nasehat pelayanan kebutuhan bagi masyarakat

5) Memberikan sanksi yang sesuai dan bersifat mendididik kepada peserta didik yang melakukan pelanggaran.

Hasil pengamatan peneliti dilapangan ditemukan pendidik memberikan sanksi kepada peserta didik yang melakukan pelanggaran dengan sanksi atau hukuman yang mendidik (program-program KKBPK) karena dengan hukuman yang mendidik akan memberikan efek jera kepada peserta didik dan secara tidak langsung akan menambah keilmuan kepada peserta didik tersebut.

Untuk mendapatkan data objektif berdasarkan pada sejumlah indikator yang dapat diamati yang valid, ${ }^{8}$ peneliti melakukan pehimpunan data melalui wawancara. Hasil wawancara dengan bapak Sarjono menjelaskan ketika ada peserta didik yang melakukan pelanggaran saya selaku Widyaiswara/Pendidik biasanya memberikan sanksi yang sedikit mendidik, seperti ketika ada siswa yang terlambat masuk ke dalam kelas pada materi saya, saya selaku pendidik memberikan hukuman hafalan nama-nama alat kontrasepsi dan jenis pungsinya bagi masyarakat.

Hukuman tersebut diharapkan peserta didik dapat mengambil manfaaat pelajaran serta efek jera sehingga tidak akan mengulangi perbuatannya lagi yang dapat merugikan orang lain terlebih merugikan diri sendiri.

b. Pembinaan tidak langsung

Pembinaan tidak langsung adalah pembinaan yang dilakukan pendidik dengan pola pembinaan melalui kegiatan-kegiatan pelayanan dalam berbagai momentum di Kab/Kota. Adapun pola yang dilakukan antara lain

1) Meningkatkan kegiatan berbagai momentum di Kab/Kota seperti hari ulang tahun Kab/Kota, Hari Kemerdekaan, hari-hari besar pada dinas instansi, dll.

2) Meningkatkan pengajaran pendidikan program KKBPK sesuai dengan agama islam

3) Meningkatkan kegiatan diskusi dan tanya jawab

4) Meningkatkan kerjasama antara Pembina

8 Rizalman dkk, Panduan sistem penjaminan mutu pada IAIN STS Jambi,CV.Bonanza Jambi Timur,2011, hlm.144 
Hasil observasi peneliti dilapangan ditemukan bentuk kolaborasi yang dilakukan Widyaiswara dengan Narasumber dari dinas instansi terkait adalah dengan cara tidak tercatat dan tercatat. Hal ini dapat dilihat pada Tabel 1.

Tabel : 1 Kerjasama Antara Widyaiswara dan Narasumber lain

\begin{tabular}{|c|c|c|}
\hline NO & Kolaborasi Tercatat & Kolaborasi tidak tercatat \\
\hline 1. & ra dan narasumber dari dinas & Koordinasi antar Perwakilan BKKBN \\
\hline & terkait berdiskusi da & Jambi dengan Dinas istansi terkait \\
\hline & $\begin{array}{l}\text { mengadakan rapat tentang pro } \\
\text { program KКВPK bagi peserta didil }\end{array}$ & program KB , terutam koordiansi denga \\
\hline
\end{tabular}
tehnik penyampaian akan lebih mudah dan menarik bagi peserta didik dalam menerima materi yang nanti akan diberikan pada peserta didik dalam kelas belajar mengajar.

2. Antara Widyaiswara dan narasumber dari BKKBN sendiri dalam hal penyampaian data-data yang diperlukan dalam pendidikan dan Pelataihan Teknis Petugas Lapangan Keluarga Berencana.

3. Antara Widyaiswara dan Kepala Bidang di Perwakilan BKKBN Provinsi Jambi membahas tentang program antaar bidang agar dapat memberikan materimateri yang ada di bidang-bidang kepada Petugas Lapangan Keluarga Berencana yang mengikuti pendidikan dan pelatihan teknis layanan KB di Balatbang

4. Kunjungan pendidik ke Kab/Kota ke tempat wilayah kerja Petugas Lapangan Keluarga Berencana. Dengan adanya kegiatan ini antara petugas lapangan dan pendidik dapat membicarakan masalahmasalah yang dihadapi dalam pelayanan Mendiskusikan perkembangan peserta didik tersebut baik ketika berada dikelas nanti setelah mereka kembali bertugas di wilayah tugas mereka di Kab/Kota. di masyarakat.

Mekanisme kolaborasi dalam upaya program-program KKBPK dalam mengatasi permasalahan yang ada di Kab/Kota terhadap layanan masyarakat yang diberikan oleh petugas lapangan di Provinsi Jambi, di mulai dari Widyaiswara sebagai impormator kepada petugas lapangan yang menjadi mediator, kemudian Kepala Latbang berkoordinasi dengan Kepala Perwakilan BKKBN Provinsi jambi untuk melakukan tindak lanjut penanganan persoalan-persoalan KKBPK di $\mathrm{Kab} /$ Kota yang bermasalah.

Salah satu bentuk kolaborasi yang dilakukan oleh Widyaiswara antara lain adalah, ketika petugas lapangan yang telah medapatkan permaslahan di dalam masyarakat seperti kebutuhan KB masyarakat yang belum dapat dipenuhi (unmedned) petugas lapangan tidak dapat menjangkau lokasi akseptor di pelosok desa sehingga susah di jangkau namun alat KB ada maka petugas lapangan akan melakukan kolaborasi dengan Kepala Bidang di Perwakilan BKKBN Provinsi Jambi yang membidangi. Sehingga nanti akan di carikan jalan keluarnya secara bersamasama. 
Secara khusus Pendidikan dan Pelatihan Teknis PLKB dalam layanan KB bagi masyarakat bertujuan untuk membantu petugas lapangan agar dapat mencapai tujuan-tujuan dalam pelayanan kepada masyarakat dalam pekerjaan di wilayah tugasnya nanti. Bimbingan pribadi sosial dimaksudkan untuk mencapai tujuan dan tugas perkembangan pribadi sosial dimaksudkan untuk mencapai tujuan dan tugas perkembangan pribadi sosial dalam mewujudkan pribadi yang taqwa, mandiri, dan bertanggung jawab. ${ }^{9}$

Dengan memahami fungsi dan perannya tersebut nantinya pendidik dapat mengarahkan dan membentuk peserta didik yang memiliki kepribadian muslim dalam memberikan layanan KB pada masyarakat, secara aktif mengembangkan potensi dirinya untuk memiliki kekuatan spiritual keagamaan, pengendalian diri, kepribadian, kecerdasan, akhlak mulia, serta keterampilan yang diperlukan dirinya, masyarakat, bangsa dan negara. ${ }^{10}$ Karena setiap aspek pendidikan dan pelatihan teknis mengandung beberapa nilai yang mengarah kepada pemahaman dan pengamalan ilmu bagi masyarakat secara menyeluruh. ${ }^{11}$

Nilai-nilai dalam pendidikan dan pelatihan teknis dan pelatihan teknis PLKB dalam layanan KB sesuai dengan sariat agama islam yang diharapkan dapat di internalisasikan melalui berbagai upaya yang dilakukan oleh pendidik yang berkolaborasi dengan Narasumber dari Dinas Instansi terkait. Nilai-nilai pendidikan dalam agama islam yang perlu di internalisasikan antara lain:

1. Ibadah

Pendidikan ibadah yang dimaksud disini adalah proses pengajaran, pelatihan, dan bimbingan dalam program-program KKBPK. Para Pendidik dan Narasumber hendaknya menjelaskan kepada peserta didik dengan penjelasan yang sangat sederhana tentang pentingnya berbagai bentuk ilmu dalam pendidikan, seperti pemahaman program KKBPK yang akan dibutuhkan oleh masyarakat agar petugas dapat memberikan penjelasan yang baik kepada masyarakat jika mereka sudah bertugas. Dan diharapkan juga kelak mereka tidak bisa meninggalkan Ibadah ke pada Allah, pekerjaaan penting namun kita beribadah akan lebih penting dari segalanya.

2. Sosial

Pendidikan sosial adalah proses pembinaan kesadaran sosial, sikap sosial, dan keterampilan sosial agar peserta didik dapat menjalankan pekerjaan ditempat tugas dapat memahami atau berjiwa sosial, bisa berbagi pengetahuan pengalaman pada masyarakat tentang program-program KB yang sangat dibutuhkan oleh masyarakat. Dengan demikian Petugas Lapangan Keluarga Berenana selain berjiwa sosial dengan berbagi ilmu pengalaman juga akan memperkuat pemahaman petugas itu sendiri.

\footnotetext{
${ }^{9}$ M. Amin Abdullah, Islamic Studies di Perguruan Tinggi (Pustaka Pelajar, 2006), hlm. 304

10 Zulfikri Anas dkk, Ibid, hlm.173

${ }^{11}$ M. Amin Abdullah, ibid, hlm.126
} 


\section{B. Penyebab Kurangnya Pemahaman Petugas Lapangan}

Penyebab kurangnya pemahaman dikarenakan petugas yang ada selain jumlahnya sedikit, petugas tersebut juga masih baru dalam menjalankan pekerjaan pelayanan tentang program-program KB yang dibutuhkan bagi masyarakat yang akan memasang alat kontrasepsi yang sesuai dan cocok untuk akseptor KB di masyarakat.

\section{Faktor Pendukung dan Penghambat Petugas Lapangan}

Petugas lapangan dalam memberikan pelayanan program-program KB bagi masyarakat mendapatkan bantuan oleh pemerintah daerah setempat dalam hal pelayanan KB baik itu Momentum, Pelayanan Massal Hari-hari Besar, dan Ulang Tahun berdirinya suatu daerah. Dalam bertugas tersebut petugas lapangan masih mendapatkan kendala, antara lain: masih ada masyarakat yang enggan mengikuti program KB, dan jarak yang akan ditempuh oleh petugas lapangan dalam melaksanakan pelayanan wilayah yang akan ditempuh masih susah di jangkau dengan menggunakan kendaraan baik roda empat maupun roda dua, serta masyarakat yang akan mengikuti kegiatan tersebut terkendala tidak mendapatkan informasi tentang adanya pelayanan KB.

Widyaiswara yang ada di Perwakilan BKKBN Provinsi Jambi ini sudah memberikan keteladanan kepada para peserta didik mereka sudah memberikan keteladanan dalam bentuk kedesiplinan, perkataan yang baik ditunnjukkan oleh peserta didik. Peserta didik yang mendapatkan pendidikan dan pelatihan di Latbang Perwakilan BKKBN Provinsi Jambi mengatakan bahwa pendidik yang ada di Latbang Perwakilan BKKBN Provinsi Jambi sudah memberikan keteladanan yang baik bagi peserta didik dari segi materi program-program KKBPK yang ada di Perwakilan BKKBN Provinsi Jambi, dan semuanya dapat membuat peserta didik lebih siap dalam menjalani pemahaman pekerjaannya.

\section{Penutup}

Berdasarkan hasil temuan peneliti yang dikemukakan terdahulu, maka dapat disimpulkan bahwa Pendidikan dan Pelatihan bagi Petugas Lapangan Keluarga Berencana di Latbang Perwakilan BKKBN Provinsi Jambi amat sangat diperlukan bagi petugas lapangan tersebut. Karena program-program KKBPK akan terus menggeliat maju atau meningkat baik dari sasaran maupun tingkat pencapaian programnya, akan sangat mustahil petugas lapangan dapat bekerja dengan baik jika pemahaman dan kemampuan mereka tentang program KKBPK dan pelayanan KB dengan beberapa jenis alat kotrasepsi saja mereka tidak menguasainya. Tingkat pertumbuhan penduduk yang akan semakin pesat sehingga berbagai kebutuhan juga akan sangat banyak maka tingkat pemahaman SDM Petugas Lapangan Keluarga Berencana harus bertambah, harus selalu diberikan pendidikan dan pelatihan agar pekerjaan mereka di lapangan akan lebih baik dan efektif. Selanjutnya secara spesifik dapat penulis simpulkan sebagai berikut: 
1) Pendidikan dan Pelatihan bagi Petugas Lapangan Keluarga Berencana di Latbang Perwakilan BKKBN Provinsi adalah proses pembelajaran untuk peningkatan kemampuan dan pengetahuan seseorang. ${ }^{12}$ Agar mereka dapat memberkan pelayanan dan penjelasan kepada masyarakat tentang alat kontrasepsi KB, karena masih banyak masyarakat yang masih awam dengan alat kontrasepsi yang nantinya akan mereka inginkan, dan akan didapat penjelasan dari petugas di Kab/Kota yang telah di latih.

2) Masih banyak Petugas Lapangan Keluarga Berencana yang belum mendapatkan pendidikan dan pelatihan dalam Layanan $\mathrm{KB}$, mereka masih sangat awam dengan program-program KKBPK yang nantinya akan dibutuhkan oleh masyarakat di Kab/Kota, Petugas Lapangan Keluarga Berencana yang ada masih banyak yang baru diangkat atau baru bertugas maka pemahaman mereka tentang program diangkat atau baru bertugas maka pemahaman mereka tentang program masih sangat sedikit. Dan Pertugas Lapangan juga perlu dibekali dengan pendidikan-pendidikan lain selain alat kontrasepsi seperti koordinasi, team work, mendata, sosial dan lain-lain sehingga pada saat mereka bertugas nanti mereka akan dapat bekerja dengan baik memberikan layanan KB yang efektif mampu menjaring informasi yang akurat dan valid sebagai dasar bagi mereka dalam bekerja bagi masyarakat. ${ }^{13}$

3) Keterbatasan jangkauan wilayah tugas dari jarak yang dapat di jangkau oleh petugas sangat jauh sedangkan alat transportasi masih sangat minim, terkadang juga biaya yang dikeluarkan tidak sesuai dengan dana yang tersedia. Serta Petugas Lapangan Keluarga Berencana juga dalam masa pendidikan perlu di perluas lagi materi yang di sampaikan, Pengembangan bahan ajar dalam pendidikan dan pelatihan petugas lapangan. Petugas lapangan juga perlu dibekali dengan pendidikan-pendidikan lain selain alat kontrasepsi seperti materi tehnik koordinasi dengan mitra kerja, team work, pendataan, sosial dan lain-lain sesuai dengan kebutuhan pekerjaan di wilayah kerja petugas lapangan KB.

\section{Bibliografi}

Budi Priyatna, dkk., Kelurga Dari Masa ke Masa, Jakarta: 2015.

Saidah, Pengantar Pendidikan Telaah Pendidikan Secara Global dan Nasional, Jakarta: Rajawali Pers, 2016.

Joko Raharjo, dkk., Pelatihan Keterangan Klinik (VTP), 2008.

Kurikulum Diklat Teknis, Direktorat Bina Ketahanan Remaja, Tahun 2013.

Rizalman dkk, Panduan sistem penjaminan mutu pada IAIN STS Jambi, Jambi: Bonanza, 2011.

12 Dewi Salma Prawiradilaga, Wawasan Teknologi Pendidikan, (Kencana Prenada Group,2014) hlm.48

13 Rizalman dkk, Panduan Sistem Penjaminan Mutu pada IAIN STS Jambi, (Sulthan Thaha Pres IAIN, 2011),hlm.144 
Suwardi

M. Amin Abdullah, Islamic Studies di Perguruan Tinggi, Yogyakarta: Pustaka Pelajar, 2006.

Zulfikri Anas dkk, Hitam putih Kurikulum 2013, Jakarta: AMP Pres dan Pustaka Bina Putra, 2014.

Dewi Salma Prawiradilaga, Wawasan Teknologi Pendidikan, Jakarta: Kencana Prenada Group, 2014. 